\title{
On the Effect of the severe Winter of 1928-1929 on the Oyster Drills (with a record of five years' observa- tions on sea-temperature on the oyster-beds) of the Blackwater Estuary.
}

\author{
By \\ J. H. Orton, D.Sc., \\ Department of Zoology, Liverpool University, \\ Assisted by \\ H. Mabel Lewis, B.A., \\ Liverpool University.
}

With 2 Figures in the Text.

DURING the year 1928 the writer was engaged in a study of the bionomics of the oyster drills on the oyster beds in the region of the River Blackwater, Essex. At this time the presence of a foreign species was detected (1) and definite records were made of the relative abundance of the three following drills or tingles:-Murex erinaceus (=0cinebra), Purpura lapillus (=Nucella), and Urosalpinx cinerea. It so happened that the winter of 1928-29 was unusually cold; the temperature of the water over the oyster beds was unusually low in January and February, 1929, ranging about the freezing-point of fresh water (see Table II and Fig. 1). The oyster-cultivators in this locality had many years previously stated that during severe winters many marine animals, such as the oyster drills or tingles and the burr Echinus miliaris, are killed in such great numbers as sometimes to exterminate the species. The observations made by the writer in 1928 offered an opportunity to test these statements, and of estimating the effect of the extreme cold in early 1929 on the animals mentioned above.

Three of the four species studied, namely, Murex, Purpura, and Echinus, are rarely found-in the district of the River Blackwaterabove low-water mark; Urosalpinx may be taken by hand in fair numbers especially in the warmer months of the year on or about oysters at extreme low-water springs. (Such a habitat is noteworthy in the case of Purpura lapillus, which is abundant on the foreshore in the Balanus balanoides zone on the coasts of Devon and Cornwall, and in some other localities.) 
The constant immersion during the winter period of the four species noted eliminates any direct effect of air temperature, and confines the influence of temperature to that of the water. Temperature readings at and about high and low water have been recorded almost daily for the writer by Mr. Laban Pearce (see 2) over a period of five years, and are recorded in Tables VII, p. 313, I and II, and Fig. 1, p. 304, being reduced to mean monthly figures. These readings prove that the mean monthly

TABLE I.

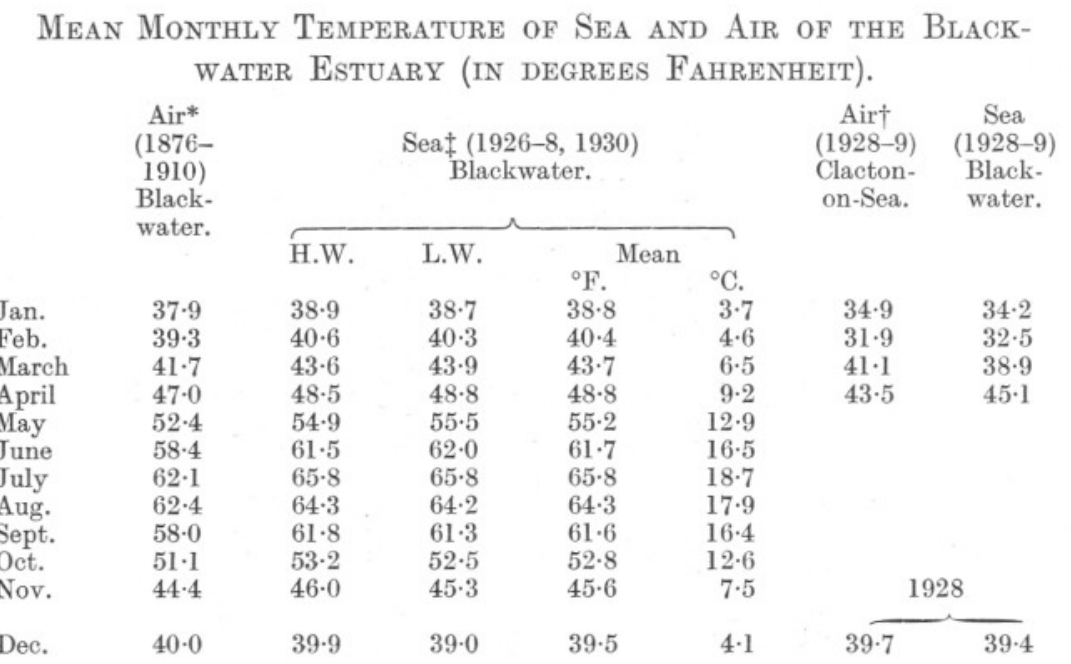

temperature of the water over the oyster beds in the River Blackwater was $4^{\circ}$ to $10^{\circ} \mathrm{F}$. below normal during most of January and February and the first week in March in 1929. The two-day means of readings (usually four) during January and February are also plotted in Fig. 1, p. 304, from the daily readings given in Table II.

The effect of this extreme cold is well shown in the analyses of catches of oyster drills made in 1928, 1929, and 1930, as given in Table III. Of the 10,852 living drills examined during the three years the percentages there shown were obtained. But, owing to the fact that the drills have different habits, it is necessary to discuss the relative abundance of the

* Mean of the monthly means of maximal and minimal readings at Clacton-on-Sea and Southend combined (see 8 M.0. 214a, App. IV).

$\dagger$ Means are only available for Clacton-on-Sea: temperatures at the more insular situations on the Blackwater are slightly lower in cold and higher in warm periods (see 7, p. 213).

$\ddagger$ Means of daily readings at about high and low water except Sundays. About 50 readings per month were made in most months. For a discussion on the significance of the readings see 2, p. 387, and legend to Fig. 1, p. 305, herein. 
animals on different types of grounds, in order to assess the significance of the figures obtained.

The environs of the mouth of the Blackwater River and the site of the oyster beds are shown in Fig. 2, p. 306. It was found in 1929 and 1930

\section{TABLE II.}

Daily Sea-temperature readings at Thornfleet* on the BlackWATER Estuary DURING THE COLD PERIOD December 1928March 1929 (to nearest degree Fahrenheit).

\begin{tabular}{|c|c|c|c|c|c|c|c|c|c|c|c|}
\hline Dec. & 17 & $\begin{array}{c}\text { L.W. } \\
37\end{array}$ & $\begin{array}{c}\text { H.W. } \\
39\end{array}$ & Jan. & 18 & $\begin{array}{c}\text { L.W. } \\
32\end{array}$ & $\begin{array}{c}\text { H.W. } \\
33\end{array}$ & Feb. & 19 & $\begin{array}{c}\text { L.W. } \\
29\end{array}$ & $\begin{array}{c}\text { H.W. } \\
30\end{array}$ \\
\hline , & 18 & 37 & 38 & , & 19 & 33 & 32 &, & 20 & 29 & 30 \\
\hline , & 19 & 36 & 37 & , & 21 & 32 & 33 & , & 21 & 31 & 32 \\
\hline , & 20 & 37 & 36 & , & 22 & 33 & 33 & , & 22 & 31 & 32 \\
\hline , & 21 & 37 & 37 & , & 23 & 34 & 34 & , & 23 & - & 33 \\
\hline , & 22 & 38 & 37 & , & 24 & 34 & 34 & , & 25 & 31 & 32 \\
\hline , & 24 & 37 & 38 & , & 25 & 34 & 34 & , & 26 & 31 & 32 \\
\hline , & 25 & - & 39 & ", & 26 & 34 & 34 & , & 27 & 30 & 31 \\
\hline " & 27 & 39 & 40 & , & 28 & 32 & 34 & , & 28 & 30 & 32 \\
\hline , & 28 & 40 & 40 & , & 29 & 32 & 34 & Mar. & 1 & 30 & 32 \\
\hline , & 29 & 39 & - & , & 30 & 34 & 34 & , & 2 & 31 & - \\
\hline , & 31 & 37 & 37 & , & 31 & 36 & 35 & ,", & 4 & 33 & 32 \\
\hline Jan. & 1 & 37 & 37 & Feb. & 1 & 37 & 35 & , & 5 & 33 & 32 \\
\hline , & 2 & 36 & 37 &, & 2 & 36 & 38 & ", & 6 & 35 & 34 \\
\hline , & 3 & 36 & 36 & , & 4 & 35 & 36 & , & 7 & 37 & 36 \\
\hline , & 4 & 35 & 35 & , & 5 & 35 & 35 & , & 8 & 38 & 36 \\
\hline , & 5 & 35 & 35 & , & 6 & 36 & 35 & , & 9 & 37 & 36 \\
\hline ", & 7 & 33 & 34 & , & 7 & 36 & 36 & , & 11 & 37 & 36 \\
\hline , & 8 & 34 & 34 & , & 8 & 37 & 36 & , & 12 & 39 & 37 \\
\hline , & 9 & 36 & 35 & , & 9 & 36 & 37 & , & 13 & 40 & 37 \\
\hline , & 10 & 35 & 35 & , & 11 & 34 & 33 & , & 14 & 39 & 37 \\
\hline , & 11 & 35 & 35 & ", & 12 & 29 & 32 & , & 15 & 38 & 37 \\
\hline ", & 12 & 33 & 34 & , & 13 & 29 & 31 & , & 16 & 38 & - \\
\hline , & 14 & 38 & 35 & , & 14 & 29 & 31 & , & 18 & 38 & 38 \\
\hline , & 15 & 34 & 35 & , & 15 & 28 & 30 & , & 20 & 41 & 39 \\
\hline , & 16 & 33 & 35 & ", & 16 & & & , & 23 & 42 & 41 \\
\hline , & 17 & 33 & 34 & , & 18 & 29 & 29 & & & & \\
\hline
\end{tabular}

\section{TABLE III.}

$\begin{array}{lcrrc} & \text { Urosalpinx. } & \text { Murex. } & \text { Purpura. } & \text { No. Total. } \\ 1928 & 7 \cdot 8 \% & 41 \cdot 2 \% & 51 \cdot 0 \% & 1,739 \\ 1929 & 83 \cdot 4 \% & 0 \cdot 1 \% & 16 \cdot 6 \% & 1,184 \\ 1930 & 84 \cdot 5 \% & 0 \cdot 1 \% & 15 \cdot 4 \% & 7,927\end{array}$

that the grounds $A_{1}, A_{2}, A_{3}$, and $A$, which are headwaters or creeks, yielded only Urosalpinx. As these grounds had not previously been carefully surveyed, it is probable that Murex, and possible that Purpura, did

* Occasional readings, which were of the same order as those obtained at Thornfleet, were also made at the following stations :-Off Tollesbury Pier, West Boundary, South Shore. Readings made from Calderara thermometer with N.P.L. certificate and read to nearest degree. 
not formerly occur there, except as occasional introductions. On the other hand, Urosalpinx had-for at least a few years before 1928-been taken there in abundance. The captures for these " A" grounds are

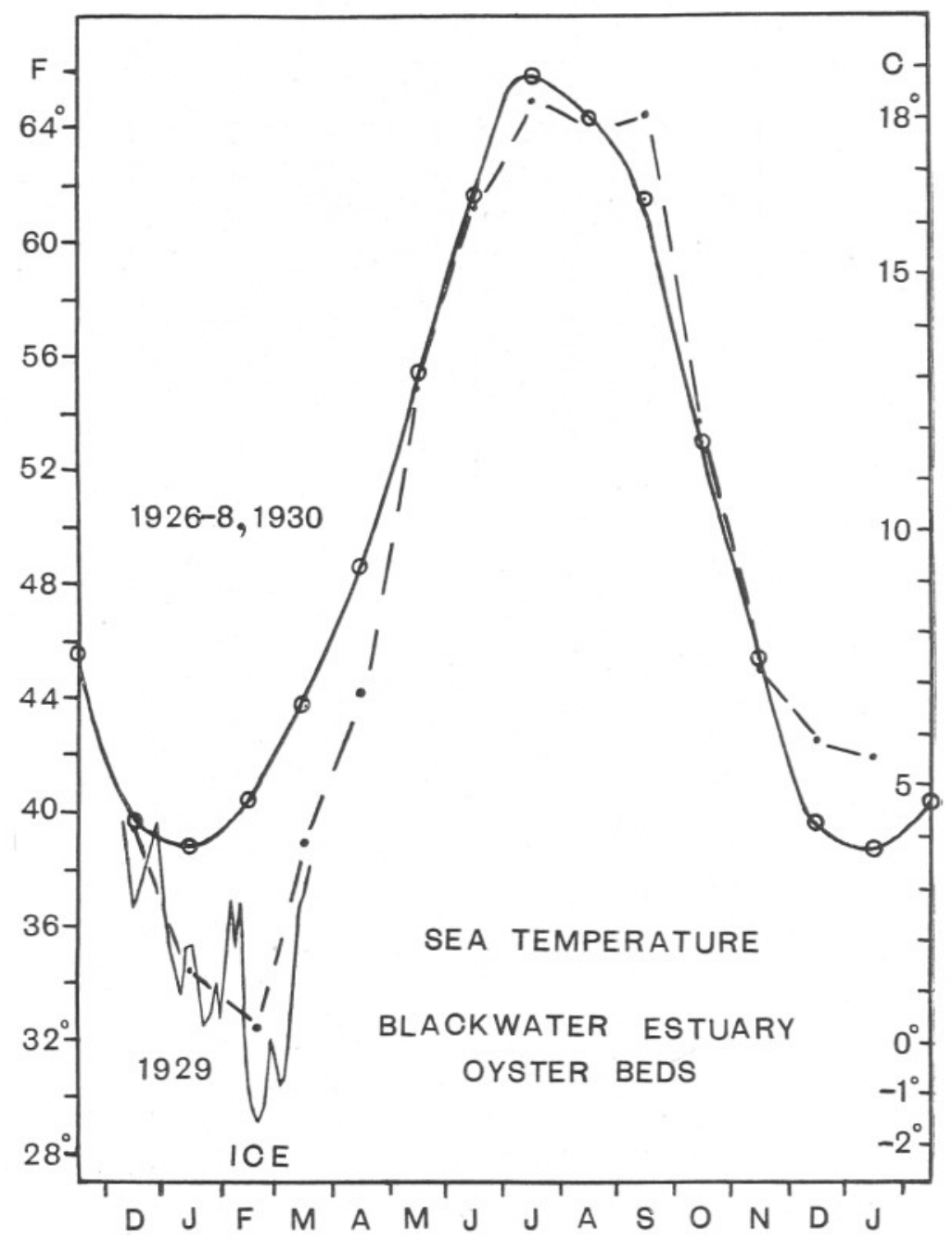

FIG. 1. (See foot of page 305.)

therefore listed separately in Table VI, p. 312, in order to permit of a direct comparison of the captures during the three years on those beds where both Murex and Purpura were known to occur in abundance in 1928. Thus, omitting the "A" grounds or creeks, the following percentages of the living tingles are obtained:- 


\section{TABLE IV.}

1928

1929

1930

Urosalpinx.
$7 \cdot 8 \%$
$71 \cdot 2 \%$
$77 \cdot 9 \%$

$\begin{array}{ccc}\text { Murex. } & \text { Purpura. } & \text { No. Total. } \\ 41 \cdot 2 \% & 51 \cdot 0 \% & 1,739 \\ 0 \cdot 2 \% * & 28 \cdot 6 \% & 584 \\ 0 \cdot 11 \% * & 22 \cdot 0 \% & 5,467\end{array}$

In this Table the yields of tingle in the three years are directly comparable and were all obtained by dredging. There can be no doubt, therefore, that after the winter of 1928-29 (a) Murex was almost eliminated from the beds, and $(b)$ that Purpura most probably also became far less abundant, $(c)$ that apparently Urosalpinx increased in abundance. The absence of any increase in the proportion of Murex and Purpura in 1930 virtually proves that these tingle were not driven into deeper water in the winter of 1928-29. There can be no doubt, therefore, that Murex did in fact suffer almost complete annihilation, and that serious mortality occurred among the Purpura. Since quantitative hauls were not made it is impossible to state that Urosalpinx actually increased in numbers, although it is probable that an increase occurred. The fishermen report that tingle as a whole were less abundant in 1930 than formerly.

FIG. 1.-Mean monthly temperature of the sea over the oyster beds in the Blackwater Estuary compiled from daily readings at a depth of about one metre (surface) at about high and low water (Sundays excepted) for the five years 1926-1930.

The means of the four years, 1926-28, 1930, are averaged to give the continuous thick-lined curve. The means for the year 1929 are shown by the discontinuous thick-lined graph; the means of readings (usually four) for each two days in the cold period, December to the middle of March, are shown in the continuous thinlined graph.

The readings were taken at the temperature stations shown in circles Fig. 2, p. 306, and mainly at the Thornfleet Station. The number of readings at each station is as follows :-

$\begin{array}{ll}\mathrm{A}_{1} & \text { Thornfleet } \\ \mathrm{C}_{1} & \text { Tollesbury Pier=Mell Pier } \\ \text { E.B. } & \text { East Boundary } \\ \text { W.B. } & \text { West Boundary } \\ \text { M. } & \text { Marfleet } \\ \text { E. } & \text { South Shore } \\ \text { S.H. } & \text { Shingle Head } \\ \mathrm{C}_{3} & \text { Nass End } \\ \text { B. } & \text { Deeps } \\ \text { A }_{4} & \text { Dan's Moorings } \\ & \text { Other stations. }\end{array}$

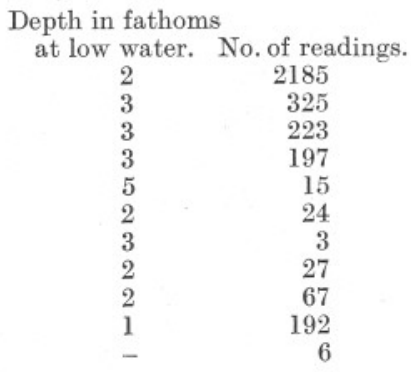

Readings below the surface rarely differ from bottom temperatures (as determined by a Nansen-Pettersen water-bottle) by more than a fraction of a degree F., at the shallower stations, i.e. where the depth of water is about 2-3 fathoms at low water. Slightly greater differences may occur between surface and bottom when the depth is greater, i.e. 5 to 10 fathoms (see 6, loc. cit., p. 6).

* All individuals small to medium in size. See Table VI, p. 312. 


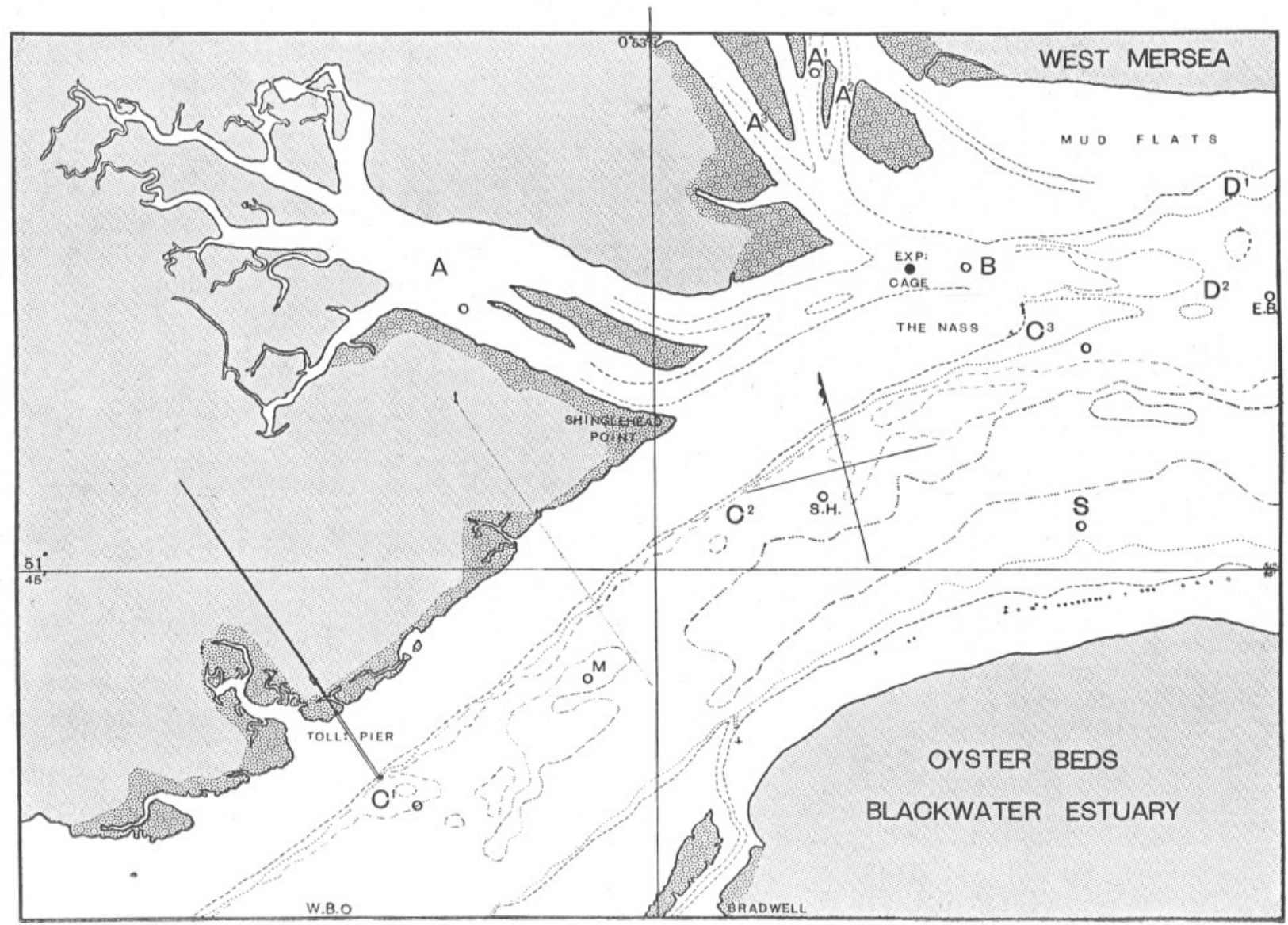


Contributory evidence to these conclusions is offered by the figures of the dead tingle obtained with the living ones. In 1929 and 1930 the dead individuals were carefully separated from the living and counted. (To prove death it was necessary to break open the doubtful shells. It was then observed that Purpura can retract itself much further into the shell than Urosalpinx, and that very badly worn and apparently empty shells of Purpura may contain an exceedingly emaciated living animal.) The proportions of dead and living shells in the catches made in 1929 and 1930 are shown in Table VI, p. 312, and summarised below in Table V. The dead shells caught in 1928 were not recorded.

\section{TABLE V.}

\begin{tabular}{lccccccccr}
\multicolumn{1}{l}{ Grounds. Urosalpinx. } & \multicolumn{2}{c}{ Murex. } & \multicolumn{2}{c}{ Purpura. } & \multicolumn{2}{c}{ Total dead. } & Total \\
B, C, D. & No. & $\%$ & \multicolumn{1}{c}{ No. } & $\%$ & No. & $\%$ & No. & $\%$ & living. \\
1929 & 16 & $3 \cdot 7$ & 25 & $96 \cdot 2$ & 17 & $9 \cdot 2$ & 58 & $9 \cdot 0$ & 584 \\
1930 & 41 & $0 \cdot 9$ & 126 & $95 \cdot 5$ & 110 & $8 \cdot 4$ & 277 & $4 \cdot 8$ & 5,467
\end{tabular}

The "A " grounds may be excluded from consideration, as it is probable that they do not constitute a natural habitat of Murex and Purpura. On the remaining grounds the total number of each species taken dead in 1929 and 1930 is shown above, along with the percentage of dead shells calculated on the total number of living and dead shells of each species. The total number of dead shells of all species is also shown, as well as the total percentage dead of the total living and dead. The very high percentages of $96 \cdot 2$ and 95.5 Murex dead, and the greater actual number of Murex dead in comparison with the total dead of Urosalpinx and Purpura, both offer additional evidence of the virtual annihilation of the rough English tingle on the Blackwater oyster beds in the winter of 1928-29.

The great increase in the percentage of living Urosalpinx on grounds C, $\mathrm{D}$, and $\mathrm{E}$ in 1929 and 1930, as shown in Tables II and III, is undoubtedly an indication of the greater capacity of this species to resist extreme cold.

FIG. 2.-Chart of the West Mersea oyster beds and temperature stations in the Blackwater Estuary. (From Admiralty Chart 3740, 1918.)

$A_{1} \quad$ Thornfleet beds.

$\mathrm{A}_{2} \quad$ Mersea Fleet beds.

$\mathrm{A}_{3} \quad$ Salcott Fleet beds.

A Tollesbury Fleet and M.V. Dan's Moorings.

B Deeps.

Exp. cage Site of experimental oyster cage.

$\mathrm{C}_{1} \quad$ Grounds off Tollesbury Pier (= Toll. Pier).

$\mathrm{C}_{2} \quad$ Grounds below Marfleet (M.) and off Shingle Head.

$\mathrm{C}_{3} \quad$ Grounds off the Nass End.

$\mathrm{D}_{1} \quad$ North shore ground near East Boundary (E.B.).

$\mathrm{D}_{2} \quad$ Offshore northern grounds (Flat Ground).

S. South shore beds near watch boat.

Thirslet Creek lies a little above Tollesbury Pier and is not shown. The tempera ture stations (shown in circles) are denoted in the legend to Fig. 1, p. 305. 
The virtual absence of Murex in the catches is at the same time an indication of the susceptibility of this species to low temperatures or conditions associated with low temperatures of the kind and duration shown in Table I; on the figures shown it is highly probable that Purpura also succumbed in considerable numbers under these unusual conditions.

Reviewing the oyster fishery as a whole it is clear that the American oyster tingle has now spread to all the grounds and has replaced the English tingles to a great extent; inasmuch as among nearly 8,000 individuals of all kinds captured in 1930, Urosalpinx occurred in percentages varying from 43 to 100 on the different beds and constituted $84 \%$ of the total captures. As Urosalpinx is known to be a voracious feeder on young oysters (1), the economic difficulties of prosecuting oyster culture on the Blackwater beds - already made difficult by the multiplication of the American slipper-limpet, Crepidula fornicata (3)-have been seriously increased. There is no evidence of unusual mortality among Crepidula on these beds as a result of the cold conditions noted, but as this species is exceedingly abundant, it is probable that a slight increase in mortality would pass unnoticed. Individuals were, however, observed to be weak and easily detachable from their chains.

The differential resistance of the specific protoplasms of (certain organs of ?) these species of Urosalpinx, Purpura, and Murex in the natural habitat to the low temperatures observed and recorded herein is apparently the cause of the selective mortality observed. It would seem that such a fundamental property of specific protoplasms is worthy of further experimental investigation on the lines of Huntsman and Sparks (4) and Battle (5).

The result of the study has proved that the observations of local naturalist-fishermen are correct as regards Murex erinaceus and (as will be shown later) Echinus miliaris, but incorrect concerning Purpura lapillus and Urosalpinx cinerea; but as the latter is not an English form and the actual date of its introduction into English waters is doubtful, it is certain that the American tingle has not been included in the consciousness of the local fishermen in the last 20 to 30 years. It is probable that Murex erinaceus was the dominant tingle on the Blackwater oyster beds until 20 to 30 years ago.

\section{ECHINUS MILIARIS.}

Echinus miliaris was abundant about and in the creek (Thirslet Creek) immediately above Ground $\mathrm{C}_{1}$ (Fig. 2, p. 306) in 1913, but rarely occurred on any of the Blackwater beds in the post-war years. It is probable that this species was exterminated from these habitats in the cold winter of 1916-17, though it survived in smaller numbers on some deeper offshore beds. During the years $1920-28$ it is known that this species occurred 
in abundance on the oyster beds off. Whitstable (6), and samples up to 500 or more have been utilised at intervals at Plymouth for transplantation, experimental work, and artificial fertilisations. In the spring of 1929, however, it was found impossible to obtain samples; it was reported that all the Echinus miliaris had been killed off during the winter on the shallower inshore grounds, but could still be obtained in small numbers in the deeper offshore waters, which are rarely worked.

The variation in the sea-temperature over the Whitstable oyster beds is comparable with that on the Blackwater beds, except that temperatures range somewhat higher in the summer and lower in the winter on the latter (8). There can be no doubt, therefore, that Echinus miliaris was exterminated as a result of the low temperatures of the winter of 1928-29 on the Whitstable oyster beds in the same way as Murex on the Blackwater beds.

It is impossible to state in what precise way the unusual reduction in temperature causes death in such instances as are noted above without experimental observations. The probable factors are:- the change in absolute temperature, the rate and period of fall or rise of temperature, and the correlated degree of salinity at different phases of change. No observations on salinity were made during the cold period, but information can be culled from data on the concomitant precipitations as compared with the normal. The monthly weather reports for the period, December 1928 to April 1929, show that the variations from monthly normals (8) in total rainfall (in mm.) were respectively December +39 , January +6 , February -19, March -32 , and April +9 . There was therefore an exceptional rainfall only in December $(17 \mathrm{~mm}$. on the $29 \mathrm{th})$, some six to seven weeks before the water was reduced to freezing-point, and exceptional dryness in March. In the coldest period there was very little dilution of the sea-water by precipitation, and no heavy rains followed in March and April during the period of rapid rise in temperature. It would seem, therefore, that the mortality observed was due mainly either to the fall in absolute temperature or the rate of change of temperature at a low level, but that the reduction in salinity at the onset of the cold period may have predisposed the animals in some degree to a lethal effect of low temperature.

\section{On Natural Selection.}

It is interesting to note that the foregoing events comprise a minor cataclasm of the kind envisaged by Bidder (9). Among the three species studied, Urosalpinx and-to a less extent-Purpura survived the (locally) unusual environmental phases. Within the species of Murex erinaceus a high degree of mortality occurred, but a small proportion of individuals survived, and may be stated to have been naturally selected. 
The surviving individuals which were captured, it is of great interest to note, were all either of small or medium size, that is, lengths in mm., 15.6 .29 , ca. $25 ; 19.5 .30,25 \cdot 3 ; 23.4 .30,29 \cdot 0,20 \cdot 8 ; 24.5 .30,32 \cdot 2,29 \cdot 0$, $25 \cdot 3$; giving an average length of about $27 \cdot 0 \mathrm{~mm}$. In 1928 a common size among the larger individuals was 40 to $45 \mathrm{~mm}$. (See 11.) It is permissible to speculate whether the surviving individuals avoided death by some peculiarity of their own or of their parents, and if so, whether that peculiarity might be heritable. There is, however, no critical evidence available on the subject in this instance, which may be regarded as typical of a series of phenomena in which Darwin considered (10) that natural selection might operate.

\section{ACKNowledgments.}

During the course of many years from 1913 to the present I have been assisted in the present studies (1) on the River Blackwater beds by Dr. J. H. Salter, Messrs. L. French, H. Mole, L. Pearce, J. Pearce, G. French, and Mr. C. Springett; and (2) on the Whitstable beds by Major A. Gardiner and Mr. E. Luckhurst. The valuable series of temperature observations was obtained in co-operation with the writer by Mr. Laban Pearce from the motor boat Dan in all kinds of weather, and by the courtesy of the Tollesbury and Mersea Native Oyster Company. The writer has spent many pleasant days afloat with Mr. Laban Pearce, who has shown special interest and care in obtaining the series of records extending over more than five years. All the work herein recorded prior to September, 1929, was accomplished while the writer was a Naturalist on the staff of the Marine Biological Association, Plymouth; the work on the River Blackwater was partly subsidised by a Government grant from the Royal Society.

\section{REFERENCES.}

1. Orton, J. H., \& Winckworth, R. The occurrence of the American oyster pest Urosalpinx cinerea (Say) on English oyster beds. Nature, 122, p. 241, 1928.

2. Orton, J. H. On rhythmic periods of shell-growth in O. edulis with a note on fattening. Journ. Mar. Biol. Ass., N.S., Vol. XV, No. 2, p. $387,1928$.

3. ORton, J. H. Is the American slipper-limpet (Crepidula fornicata) an oyster pest? Nature, 117, p. 304, 1926.

4. Huntsman, A. G., \& Sparks, M. I. Limiting factors for marine animals. (3) Relative resistance to high temperatures. Contributions to Canadian Biol., N.S., Vol. II, 6, pp. 97-114, 1924. 
5. Battle, H. I. Effects of extreme temperatures on muscle and nerve tissue in marine fishes. Trans. Roy. Soc. Canada, 3rd Ser., Vol. XX, Pt. 1, Section V, pp. 127-143, Jan. 1926.

6. ORton, J. H. Fishery Investigations, Ser. II, Vol. 6, No. 4, 1924, p. 4. London.

7. ORton, J. H. On lunar periodicity in spawning of normally grown Falmouth oysters in 1925, with a Comparison of the Spawning Capacity of normally grown and dumpy Oysters. Journ. Mar. Biol. Ass., N.S., Vol. XIV, No. 1, p. 213, 1926.

8. - Monthly normals of temperature, rainfall and sunshine, M.O. 214a, App. IV, 1915, and M.O. 236 (Section 1), 1919. Meteorological Office, London.

9. Bidder, G. P. The importance of cataclasms in evolution. Proc. Linn. Soc., Feb. 6, 1930, and Nature, Vol. 125, p. 783, 1930.

10. Darwin, C. The origin of species by means of natural selection, 6th ed., p. 63, 1891.

11. Orton, J. H. Habitats and feeding habits of Ocinebra erinacea. Nature, Vol. 124, p. 371, 1929. 
TABLE VI.

Analysis of Captures of Oyster Drills on the Oyster Beds in the Blackwater Estuary, 1928-30.*

1928

\begin{tabular}{ll}
$\begin{array}{c}\text { Chart } \\
\text { reference. }\end{array}$ & \multicolumn{1}{c}{$\begin{array}{c}\text { Designation } \\
\text { of bed. }\end{array}$} \\
$\mathrm{B}$ & Deeps \\
$\mathrm{B}_{-} \mathrm{A}_{1}, \mathrm{Thornfleet}$ and Deeps \\
$\mathrm{C}_{1}, \mathrm{D}, \mathrm{E}$ & $\begin{array}{l}\text { T. Pier, S. Shore, } \\
\text { Flat Ground }\end{array}$ \\
$\mathrm{C}_{1}$ & $\begin{array}{c}\text { T. Pier-Nass End } \\
\mathrm{C}_{2}-\mathrm{D}\end{array}$ \\
$\begin{array}{c}\text { Back of Nass and } \\
\text { Flat Ground }\end{array}$ \\
$\mathrm{C}_{2-3}$ & Back of Nass
\end{tabular}

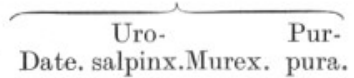

$\begin{array}{llll}31 / 8 & 44 & 31 & 0\end{array}$

N.R.

$17 / 10 \quad 46 \quad 262 \quad 325$

$26 / 10 \quad 45 \quad 423 \quad 563$

$\mathrm{C}_{2-3} \quad$ Back of Nass

D Flat Ground, N.

D N.E. Ground near

E. Boundary

Flat Ground, do.

Totals

$\%$ living

Gross total for year

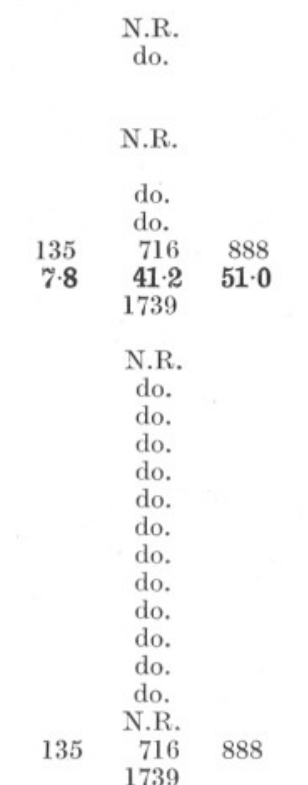

Thornfleet

do.

do.

Mersea Fleet

do.

Salcott Fleet

do.

Tollesbury Fleet

do.

do.

do.

Totals " A " Grounds

Totals all Grounds

Gross yearly total

* The numbers in italics refer to dead animals.
1930

$\overbrace{\begin{array}{c}\text { Uro- } \\ \text { Dalpinx. } \\ \text { Date. }\end{array}}^{\text {Murex. Pur- }}$

15/6 N.R. $\dagger$

$1+16$

$96+11$

N.R.

do.

Date.

Uro-

$\begin{array}{rrrr}2 / 6 & 88+0 & 0+0 & 3+0 \\ 6 / 7 & 15+2 & 0+9 & 68+6\end{array}$

$13 / 5$

$692+8$

N.R

$$
\text { (n) }
$$

$\begin{array}{cc}29 / 4 & 361+3 \\ & \\ 19 / 5 & 885+12 \\ 24 / 5 & 1875+15 \\ & 4258+41 \\ & 79 \cdot 9\end{array}$

$$
0+7
$$$$
41+13
$$

$1+33$

$3+47$

$61+126$

$\mathbf{0} \cdot \mathbf{1}$

$123+23$

$258+31$

$1203+110$

$22 \cdot 0$

$5467+277$

$\begin{array}{llll}2 / 7 & 135+4 & 0+1 & 11+0 \\ 9 / 7 & 214+6 & 0+4 & 12+2\end{array}$

$28 / 3 \quad 15+0$

$4 / 5 \quad 30+0$

$\begin{array}{ll}16 / 6 & 100+0 \\ 19 / 6 & 290+3\end{array}$

$\begin{array}{lllllr}7 / 6 & 115+0 & 0+0 & 0+0 & 20 / 2 & 20+0\end{array}$

$\begin{array}{llllll}7 / 11 & 107+1 & 0+0 & 6+0 & 20 / 5 & 386+2\end{array}$

$23 / 5 \quad 101+0$

$13 / 5 \quad 160+1$

$\begin{array}{rr}20 / 2 & 81+0 \\ 13 / 5 & 310+3\end{array}$

$\begin{array}{ll}13 / 5 & 310+3 \\ 22 / 5 & 424+0\end{array}$

$30 / 5 \quad 208+0$

$6 / 6$

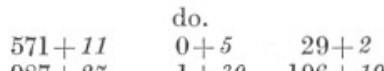

$\begin{array}{lll}987+27 & 1+30 & 196+19\end{array}$

$0+0$
$0+0$
$0+0$
$0+3$
$0+0$
$0+0$
$0+0$
$0+0$
$0+0$
$0+0$
$0+0$
$0+0$
$0+0$
$0+3$
$6+129$
$927+292$

$0+0$

$0+0$

$1+1$

$3+2$

$1+0$

$1+0$

$0+0$

$0+0$

$0+0$

$0+0$

$4+0$

$4+0$

$1+0$

$1+0$
$16+3$

$319+0$
$2444+9$

$6702+50$

$16+3$

$1219+113$

$\dagger$ N.R. No record.

$\ddagger$ Individuals of small or medium size. 


\section{TABLE VII.}

Mean Monthly Temperature of the Sea over the Oyster Beds in the Blackwater Estuary for the period OCtober 1925 to December 1930. (From daily observations at about High and Low water (except Sunday), mainly at Thornfleet and Tollesbury Pier Stations (see Fig. 1 and description, p. 305).

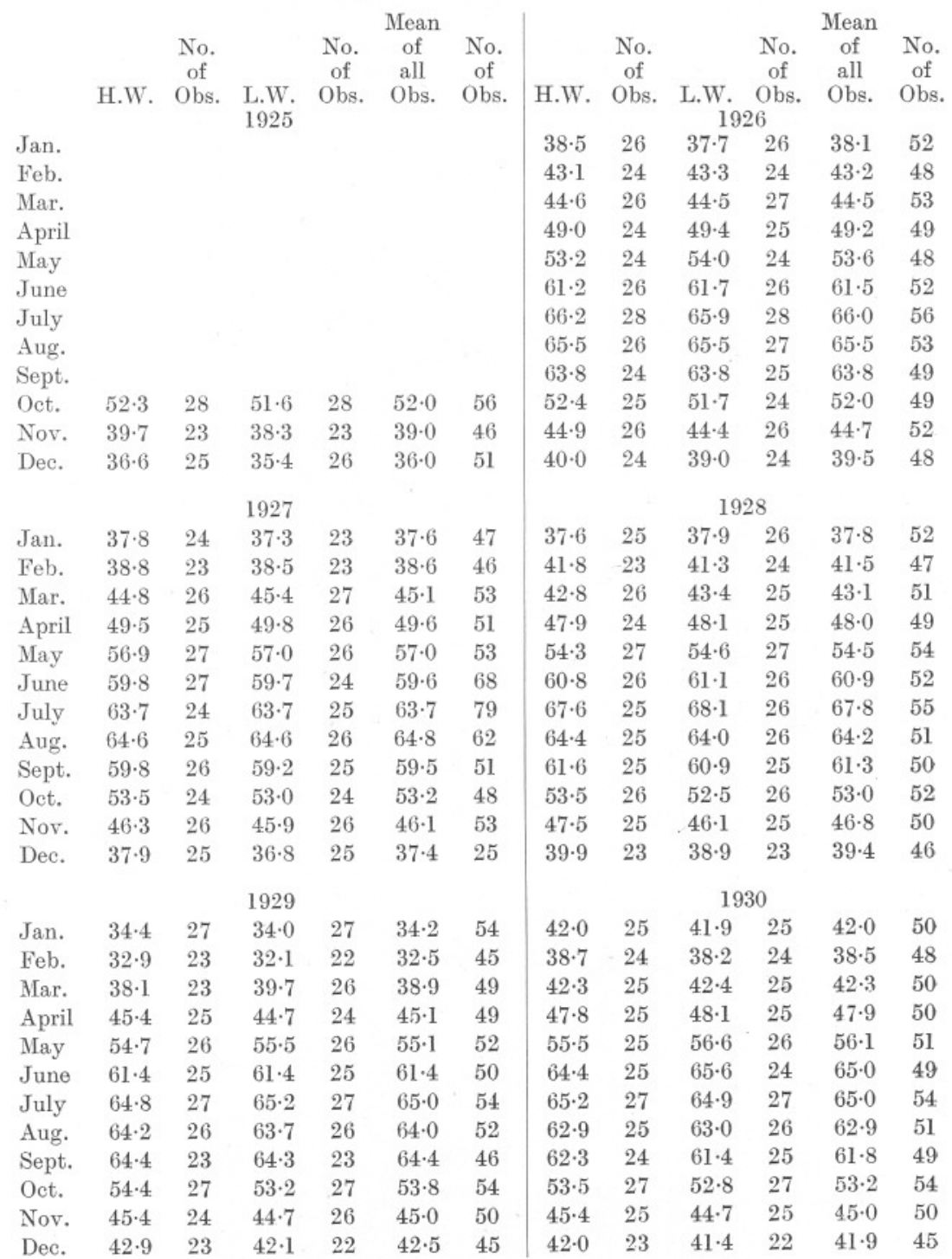


